\title{
Screening of Mung Bean Genotypes against Whitefly and Yellow Mosaic Viral Disease under Field Condition in Bihar (India)
}

\author{
Vinodakumargoud Patil ${ }^{1 *}$, P.P. Singh ${ }^{1}$, K. Akshay Kumar ${ }^{2}$ and Nityashri ${ }^{1}$ \\ ${ }^{1}$ Department of Entomology, Dr. Rajendra Prasad Central Agricultural University, \\ Pusa, Bihar- 848125, India \\ ${ }^{2}$ Department of Entomology, UAS, Raichur, India \\ *Corresponding author
}

\section{A B S T R A C T}

Keywords

Whitefly, MYMV,

Screening of genotypes,

Mung bean, Vegetative

stage, Reproductive

stage

Article Info

Accepted:

20 November 2018

Available Online:

10 December 2018
Among sixteen mung bean genotypes evaluated against whitefly and MYMV disease incidence, four genotypes viz., SMP17-17, SMP17-18, SMP17-24 and SMP17-25 recorded less number of whitefly (1.62 to 3.2 /trifoliate leaf) with disease incidence of 1 to 10 per cent and were categorized as resistant $(\mathrm{R})$ with disease rating 3, four genotypes viz., SMP17-19, SMP17-20, SMP17-21 and SMP17-29 exhibited 11-20 per cent MYMV disease incidence having disease rating scale 5 and categorized as moderately resistant (MR) and remaining eight genotypes viz., SMP17-22, SMP17-23, SMP17-26, SMP17-27, SMP1728, SMP17-30, SMP17-31 and LGG-450 were categorized as susceptible (S) against MYMV disease rating scale 7 showing disease incidence 21 to 50 per cent.

\section{Introduction}

Mung bean, Vigna radiata (L.) R. Wilczek belongs to the family Fabaceae chromosome no $2 n=24$ originated in India and central Asia and it was commonly known as green gram or mung is a vital crop grown throughout Asia, Australia, West Indies, South and North America, tropical and subtropical Africa. Being a short duration crop, it is well suited to a large number of cropping systems and constitutes an important source of cerealbased diet. In India, it is mostly grown in summer and Kharif season in an area of 3.02 million ha, total production of 1.55 million tonnes with a productivity of $498 \mathrm{~kg} / \mathrm{ha}$ as against 0.168 million ha of the area, total production of 0.100 million tonnes with the productivity of $596 \mathrm{~kg} / \mathrm{ha}$ in Bihar (Anonymous., 2016). Like other pulses, mung bean also fixes atmospheric nitrogen. The stem and foliage parts serve as good source of fodder for livestock as well as green manure.

Despite its importance, the yield of mung bean is very low in Bihar as compare to other states 
and its area and production has not considerably increased. The main reason for the low yield is the susceptibility of the crop to insects and diseases. Most of these insects are polyphagous in nature and feed on wide range of leguminous and non-leguminous crops. According to Lal (1985) about 64 species of insects are known to attack this crop. Among sucking insects pests, whitefly, Bemisia tabaci (Hemiptera: Aleyrodidae) is of major importance. Both nymphs and adults of whitefly suck the cell sap from leaves causing loss of plant vigor and reduce crop yield. Apart from direct injury it also damages the crop indirectly as a vector transmitting a viral disease known as mung bean yellow mosaic virus (MYMV).

The yellow mosaic virus disease of mung bean caused 30-70\% yield loss (Marimuthu et al., 1981). The virus affected plants have yellow and green specks or patches on the leaves which finally turn entire yellow resulting affected plants bear fewer flowers and pods containing smaller and shrunken seeds thus affecting yields qualitatively and quantitatively.

Reduction in number of pods/plant, seeds/pod and seed weight are the main contributing factors for yield reduction (Nene, 1973; Dhingra and Chenulu, 1985). In changing climatic scenario, the incidence of whitefly and severity of yellow mosaic virus disease on mung bean are a major cause of unsuccessful cultivation of mung bean and low production in Bihar. Keeping in view above facts, the present study is undertaken to study the infestation status of whitefly on mung bean and to know the effect of different genotypes of mung bean in the context of the agroecological situation of north Bihar.

\section{Materials and Methods}

Sixteen mung bean genotypes were screened for their comparative susceptibility to mung bean against whitefly and yellow mosaic viral disease under natural infestations at the research farm T.C.A. Dholi (Muzaffarpur) during the summer season, 2017. These genotypes were grown by adopting all the recommended agronomic practices uniformly but keeping them completely free from insecticidal contamination in order to support the population of whitefly for the natural spread of disease incidence. Sowing was done on $30^{\text {th }}$ March, 2017 in the crop season. The experiment was laid out in Randomized Block Design (RBD) with two replications.

Each test entry was planted in two consecutive rows of 3 meter long with $30 \mathrm{~cm}$ row to row and $15 \mathrm{~cm}$ plant to plant distance. One row of the susceptible check (LGG-450) was sown after every test entry. Two rows of the susceptible check (LGG-450) were also sown all around the experiment to create more pest pressure and increase disease incidence.

The test genotypes were closely examined at regular intervals. The observations with regard to number of whitefly (Bemisia tabaci Genna.) were recorded on three leaves, viz. one each from top, middle, and lower portion of five randomly selected plants in each replication. The MYMV disease occurrence was noticed from $25^{\text {th }}$ day after sowing. The population of whitefly was counted during morning hours at 7AM with the help of magnifying hand lens. The disease incidence was recorded on plants selected randomly at vegetative and reproductive stage of the crop. These data were used to work out the average number of whitefly population per trifoliate leaf and percent disease incidence was calculated by using these following formulas.

Mean no.of whitefly per plant $=\frac{\mathrm{n} 1+\mathrm{n} 2 \ldots \ldots \ldots \ldots+\mathrm{n} 5}{5}$

Where " $n$ " denotes number whitefly per plant numbering 1 to 5 . 
Per cent disease incidence

$=\frac{\text { Number of plants infected in a row }}{\text { Total number of plants in a row }} \times 100$
The susceptibility/ resistance of different genotypes were categorized/ determined on the basis of 0-9 scale (Mayee and Datar, 1986).

\begin{tabular}{|c|c|c|}
\hline Scale & Description & Reaction \\
\hline 0 & No plants showing any symptoms. & Free \\
\hline 1 & Less than $1 \%$ plants showing symptoms. & Highly Resistant (HR) \\
\hline 3 & $1-10 \%$ plants showing mottling of leaves. & Resistant (R) \\
\hline 5 & $11-20 \%$ showing mottling and yellow discoloration of leaves. & Moderately Resistant (MR) \\
\hline 7 & $\begin{array}{l}21-50 \% \text { plants showing mottling and yellow discoloration of } \\
\text { leaves, stunting of plants. }\end{array}$ & Susceptible (S) \\
\hline 9 & $\begin{array}{l}51 \% \text { or more plants affected. Stunting of plants pronounced. } \\
\text { Flower and fruit set reduced. Yellow mottling severe. }\end{array}$ & Highly Susceptible (HS) \\
\hline
\end{tabular}

\section{The details of mung bean genotypes used during experiment}

\begin{tabular}{|l|l|}
\hline Genotypes No. & Mung bean genotypes \\
\hline $\mathbf{V}_{1}$ & SMP17-17 \\
\hline $\mathbf{V}_{2}$ & SMP17-18 \\
\hline $\mathbf{V}_{3}$ & SMP17-19 \\
\hline $\mathbf{V}_{4}$ & SMP17-20 \\
\hline $\mathbf{V}_{5}$ & SMP17-21 \\
\hline $\mathbf{V}_{6}$ & SMP17-22 \\
\hline $\mathbf{V}_{7}$ & SMP17-23 \\
\hline $\mathbf{V}_{8}$ & SMP17-24 \\
\hline $\mathbf{V}_{9}$ & SMP17-25 \\
\hline $\mathbf{V}_{10}$ & SMP17-26 \\
\hline $\mathbf{V}_{11}$ & SMP17-27 \\
\hline $\mathbf{V}_{12}$ & SMP17-28 \\
\hline $\mathbf{V}_{13}$ & SMP17-29 \\
\hline $\mathbf{V}_{14}$ & SMP17-30 \\
\hline $\mathbf{V}_{15}$ & SMP17-31 \\
\hline $\mathbf{V}_{16}$ & LGG-450 (check) \\
\hline
\end{tabular}

\section{Results and Discussion}

Screening of mung bean genotypes against whitefly and mung bean yellow mosaic virus disease

As many as sixteen genotypes of mung bean grown during summer season, 2017 under open field conditions, were screened against whitefly, MYMV disease incidence and identify the sources of resistance at research farm of T.C.A, Dholi, Muzzaffarpur, Bihar. The results are presented in Tables 1-4.
Screening of mung bean genotypes against whitefly and MYMV disease incidence

In terms of whitefly population and MYMV disease incidence, the mung bean genotypes under test varied significantly in their reaction to whitefly and MYMV disease incidence during summer season 2017 (Table 1). The data presented in Table 1 clearly revealed that mean number of whitefly/trifoliate leaves varied significantly from 1.6 to 9.2 whitefly/trifoliate leaf with minimum and maximum being in genotypes SMP17-18 and 
LGG-450 (Check), respectively. Among the different mung bean genotypes, SMP17-21 (3.0 whitefly/trifoliate leaf), SMP17-17 (3.2 whitefly/trifoliate leaf) and SMP17-25 (3.5 whitefly/trifoliate leaf) which recorded lower population of whitefly were statistically at par with SMP17-18. Among the remaining genotypes only four genotypes viz., SMP1723 (8.9 whitefly/trifoliate leaf), SMP17-26 (7.8 whitefly/trifoliate leaf), SMP17-27 (7.5 whitefly/trifoliate leaf), and SMP17-28 (7.1 whitefly /trifoliate leaf) suffered most due to attack of whitefly and were statistically at par with LGG-450 (9.2 whitefly/trifoliate leaf). Remaining genotypes occupied intermediate position.

As regards the extent of incidence of mung bean yellow mosaic virus (MYMV) transmitted by whitefly too, mung bean genotypes were found to differ significantly during the crop season (Table 1). Among sixteen genotypes under test, the extent of MYMV disease incidence ranged from 4.6 to 49.1 per cent. SMP17-18 registered lowest disease incidence (4.6\%) which was statistically at par withSMP17-17, SMP17-25 and SMP17-24 which recorded MYMV disease incidence of 8.2 per cent, 9.5 per cent and 9.6 per cent, respectively. Genotype LGG-450 used as a highly susceptible check was found to suffer most $(49.1 \%)$ due to MYMV disease incidence and was statistically at par with SMP17-23 (48.6\%),SMP17-27 (48.2\%), SMP17-28 (48.1\%),SMP17-31 (47.4\%),SMP17-26 $(46.2 \%)$ and SMP17-22(46.4\%), while remaining genotypes occupied intermediate position in between them.

A perusal of the results presented in Table 1 clearly revealed that various mung bean genotypes under test responded to whitefly infestation and MYMV disease incidence differently when these two parameters were taken separately as the basis for evaluating them. However, few genotypes namely SMP17-18, SMP17-21, SMP17-17 and SMP17-25 showed better performance in recording lower number of whiteflies (1.6, 3.0, 3.2 and 3.5 whitefly/ trifoliate leaf) as well as less MYMV disease incidence (4.6, $18.9,8.2$ and $9.6 \%$ ), respectively, as against 9.2 whitefly/trifoliate leaf and 49.1 per cent MYMV disease incidence in highly susceptible check i.e. LGG-450. Remaining genotypes showed either susceptible or highly susceptible against whitefly and MYMV disease incidence. Similar type of varietal evaluations against whitefly and MYMV disease incidence on mung bean, urd bean and other crops were previously documented by several workers (Chenulu et al., 1979; Singh et al., 1980; Mayee and Datur, 1986; Patel and Srivastva, 1990A; Chabhar and Kooner, 1998 A and B; Naqui et al., 1995; Siddique et al., 1999; Nair et al., 2013; Yadav and Dahiya, 2014; Suman et al.,2015; Iqbal et al., 2011 and Taggar et al., 2013).

\section{Effect of different genotypes on population of whitefly at different stages of mung bean}

The population of whitefly at vegetative and reproductive stage of mung bean under different genotypes has been shown in Table 2. The data showed that the lowest number of whitefly (1.0 whitefly/trifoliate leaf at vegetative stage and 0.6 whitefly/trifoliate leaf at reproductive stage) was found in SMP17-18. Among the remaining genotypes SMP17-17 occupied second position in recording lower number of whitefly (1.8 whitefly/trifoliate leaf) which was statistically at par with the best genotype i.e. SMP17-18 while SMP17-23 recorded maximum whitefly population (5.7 whitefly/trifoliate leaf) which was statistically at par with check viz., LGG450 (5.6 whitefly/trifoliate leaf) and SMP1726 (4.7 whitefly/trifoliate leaf at vegetative stage). 
Table.1 Screening of mung bean genotypes against whitefly and MYMV disease during summer season, 2017

\begin{tabular}{|c|c|c|}
\hline Genotype & Mean no. of whitefly/ trifoliate leaf & MYMV disease incidence (\%) \\
\hline V $_{1}$-SMP17-17 & 3.2 & 8.2 \\
\hline $\mathrm{V}_{2-S M P 17-18}$ & 1.6 & 4.6 \\
\hline $\mathrm{V}_{3}$-SMP17-19 & 4.2 & 19.1 \\
\hline $\mathrm{V}_{4}$-SMP17-20 & 4.0 & 19.3 \\
\hline $\mathrm{V}_{5-\mathrm{SMP}} 17-21$ & 3.0 & 18.9 \\
\hline $\mathrm{V}_{6}$-SMP17-22 & 6.4 & 46.4 \\
\hline 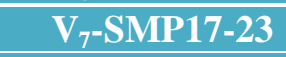 & 8.9 & 48.6 \\
\hline $\mathrm{V}_{8-\mathrm{S} M P 17-24}$ & 3.9 & 9.6 \\
\hline V9-SMP17-25 & 3.5 & 9.5 \\
\hline$V_{10-S M P 17-26}$ & 7.8 & 46.2 \\
\hline $\mathrm{V}_{11-S M P 17-27}$ & 7.5 & 48.2 \\
\hline $\mathrm{V}_{12-S M P 17-28}$ & 7.1 & 48.1 \\
\hline $\mathrm{V}_{13}$-SMP17-29 & 4.7 & 15.6 \\
\hline $\mathrm{V}_{14-\mathrm{S} M I P 17-30}$ & 4.8 & 40.5 \\
\hline V $_{15}$-SMP17-31 & 5.0 & 47.4 \\
\hline $\begin{array}{c}\mathrm{V}_{16} \text {-LGG-450 } \\
\text { (Check) }\end{array}$ & 9.2 & 49.1 \\
\hline S.Em $( \pm)$ & 0.65 & 1.73 \\
\hline CD at $5 \%$ & 1.9 & 5.3 \\
\hline CV (\%) & 17.2 & 8.1 \\
\hline
\end{tabular}

Table.2 Population of whitefly at different stages of mung bean in different genotypes during summer season, 2017

\begin{tabular}{|c|}
\hline Genotype \\
\hline V1-SMIP17-17 \\
\hline $\mathrm{V}_{2}$-SMIP17-18 \\
\hline $\mathrm{V}_{3}$-SMP17-19 \\
\hline $\mathrm{V}_{4}$-SMP17-20 \\
\hline $\mathrm{V}_{5}$-SMP17-21 \\
\hline $\mathrm{V}_{6}$-SMP17-22 \\
\hline $\mathrm{V}_{7-S M P 17-23}$ \\
\hline $\mathrm{V}_{8-S M I P 17-24}$ \\
\hline $\mathrm{V}_{9}$-SMP17-25 \\
\hline $\mathrm{V}_{10-}$-SMP17-26 \\
\hline $\mathrm{V}_{11-S M P 17-27}$ \\
\hline $\mathrm{V}_{12-\mathrm{SMP17-28}}$ \\
\hline $\mathrm{V}_{13-}$-SMP17-29 \\
\hline V $_{14-S M P 17-30}$ \\
\hline $\mathrm{V}_{15}$-SMP17-31 \\
\hline $\mathrm{V}_{16}$-LGG-450 (Check) \\
\hline $\begin{array}{l}\text { S.Em }( \pm) \\
\text { CD at } 5 \% \\
\text { CV }(\%)\end{array}$ \\
\hline
\end{tabular}

\begin{tabular}{|c|c|}
\hline \multicolumn{2}{|c|}{ Mean population of whitefly/ trifoliate leaf at } \\
Regetative stage & 1.4 \\
\hline 1.8 & 0.6 \\
\hline 1.0 & 1.0 \\
\hline 3.2 & 1.6 \\
\hline 2.4 & 1.0 \\
\hline 2.0 & 1.9 \\
\hline 4.5 & 3.2 \\
\hline 5.7 & 1.5 \\
\hline 2.4 & 1.5 \\
\hline 2.0 & 3.1 \\
\hline 4.7 & 3.3 \\
\hline 4.2 & 3.0 \\
\hline 4.2 & 1.9 \\
\hline 2.8 & 1.6 \\
\hline 3.2 & 2.1 \\
\hline 2.9 & 3.6 \\
\hline 5.6 & 0.27 \\
\hline 0.32 & 0.8 \\
\hline 0.9 & 19.2 \\
\hline 13.6 & \\
\hline
\end{tabular}


Table.3 Screening of mung bean genotypes against MYMV disease at different stages of crops during summer season, 2017

\begin{tabular}{|c|}
\hline Genotype \\
\hline $\mathbf{V}_{1}$-SMP17-17 \\
\hline $\mathbf{V}_{2}$-SMP17-18 \\
\hline $\mathbf{V}_{3}$-SMP17-19 \\
\hline $\mathbf{V}_{4}$-SMP17-20 \\
\hline $\mathbf{V}_{5}$-SMP17-21 \\
\hline $\mathbf{V}_{6}$-SMP17-22 \\
\hline $\mathbf{V}_{7}$-SMP17-23 \\
\hline $\mathbf{V}_{8}$-SMP17-24 \\
\hline $\mathbf{V}_{9}$-SMP17-25 \\
\hline $\mathbf{V}_{10}$-SMP17-26 \\
\hline $\mathbf{V}_{11}$-SMP17-27 \\
\hline $\mathbf{V}_{12}$-SMP17-28 \\
\hline $\mathbf{V}_{13}$-SMP17-29 \\
\hline $\mathbf{V}_{14}$-SMP17-30 \\
\hline $\mathbf{V}_{15}$-SMP17-31 \\
\hline $\mathbf{V}_{16}$-LGG-450 (Check) \\
\hline S.Em $( \pm)$ \\
\hline CD at 5\% \\
CV $(\%)$ \\
\hline
\end{tabular}

\begin{tabular}{|c|c|}
\hline \multicolumn{2}{|c|}{ MYMV disease incidence at } \\
\hline Vegetative stage & 3.2 \\
\hline 5.0 & 2.0 \\
\hline 2.6 & 9.0 \\
\hline 10.1 & 8.1 \\
\hline 11.2 & 7.4 \\
\hline 10.8 & 22.2 \\
\hline 24.2 & 21.2 \\
\hline 27.4 & 3.6 \\
\hline 6.0 & 3.1 \\
\hline 6.4 & 20.0 \\
\hline 26.2 & 20.2 \\
\hline 28.0 & 23.1 \\
\hline 25.0 & 7.2 \\
\hline 8.4 & 19.2 \\
\hline 21.6 & 22.1 \\
\hline 25.3 & 20.0 \\
\hline 21.1 & 0.79 \\
\hline 1.19 & 2.4 \\
\hline 3.6 & 8.5 \\
\hline
\end{tabular}

Table.4 Categorization of mung bean genotypes on the basis of MYMV disease incidence scale

\begin{tabular}{|c|c|c|c|}
\hline $\begin{array}{l}\text { Disease severity } \\
\text { (Disease scale) }\end{array}$ & Categories & $\begin{array}{c}\text { No. of } \\
\text { Genotypes. }\end{array}$ & Accessions \\
\hline 0 & Free & 0 & - \\
\hline 1 & Highly Resistant & 0 & - \\
\hline 3 & Resistant (R) & 4 & $\begin{array}{l}\mathrm{V}_{1}-\mathrm{SMP} 17-17 \\
\mathrm{~V}_{2} \text {-SMP17-18 } \\
\mathrm{V}_{8} \text {-SMP17-24 } \\
\mathrm{V}_{9} \text {-SMP17-25 }\end{array}$ \\
\hline 5 & Moderately Resistant (MR) & 4 & $\begin{array}{c}\mathrm{V}_{3}-\mathrm{SMP} 17-19 \\
\mathrm{~V}_{4}-\mathrm{SMP} 17-20 \\
\mathrm{~V}_{5}-\mathrm{SMP} 17-21 \\
\mathrm{~V}_{13} \text {-SMP17-29 }\end{array}$ \\
\hline 7 & Susceptible (S) & 8 & $\begin{array}{l}\mathrm{V}_{6} \text {-SMP17-22 } \\
\mathrm{V}_{7} \text {-SMP17-23 } \\
\mathrm{V}_{10} \text {-SMP17-26 } \\
\mathrm{V}_{11-\mathrm{SMP} 17-27} \\
\mathrm{~V}_{12} \text {-SMP17-28 } \\
\mathrm{V}_{14-\mathrm{SMP}} 17-30 \\
\mathrm{~V}_{15} \text {-SMP17-31 } \\
\mathrm{V}_{16} \text {-LGG-450 }\end{array}$ \\
\hline 9 & Highly Susceptible (HS) & 0 & - \\
\hline
\end{tabular}


At reproductive stage, less number of whitefly were recorded in all genotypes as compared to vegetative stage. However, the lowest population of whitefly was recorded in SMP17-18 (0.6 whitefly/trifoliate leaf) which was statistically at par with SMP17-19 (1.0 whitefly/trifoliate leaf), SMP17-21 (1.0 whitefly/trifoliate leaf) and SMP17-17 (1.4 whitefly/trifoliate leaf).

The maximum population of whitefly was recorded in check i.e. LGG-450 (3.6 whitefly/trifoliate leaf) followed by SMP1727 (3.3 whitefly/trifoliate leaf), SMP17-26 (3.1 whitefly/trifoliate leaf) and SMP17-28 (3.0 whitefly/trifoliate leaf) with no significant difference between them. Remaining genotypes showed intermediate position at reproductive stage.

The results of the study revealed that all the genotypes recorded higher number of whitefly at vegetative stage (45 days after sowing) as compared to reproductive stage (65 days after sowing) which might be due to thickness of leaves, plant attained maturity, hardening of leaves and migration of whitefly.

However, SMP17-18 recorded lowest whitefly population $(1.0$ and 0.6 whitefly/trifoliate leaf) followed by SMP1717 (1.8 and 1.4 whitefly/trifoliate leaf at vegetative and reproductive stage, respectively). Maximum population of whitefly was recorded in SMP17-23(5.7 whitefly/trifoliate leaf) as against in check LGG-450 (5.6 whitefly/trifoliate leaf) at vegetative stage while SMP17-26 (3.1 whitefly/trifoliate leaf), SMP17-27 (3.3 whitefly/trifoliate leaf) and SMP17-28 (3.0 whitefly/trifoliate leaf) showed poor performance and suffered most due to attack of whitefly with non significant difference with Check LGG-450 (3.6 whitefly/trifoliate leaf) at reproductive stage.
Effect of different genotypes on MYMV disease incidence at different stages of mung bean

The effect of mung bean genotypes on incidence of mung bean yellow mosaic virus disease at vegetative and reproductive stage is shown in Table 3. The mean per cent disease incidence varied from 2.6 to 28.0per cent with minimum and maximum in SMP17-18 and SMP17-27, respectively as against 21.1 per cent in highly susceptible check (LGG-450) at vegetative stage. Among the remaining genotypes, SMP17-17 and SMP17-24 recorded lower level of MYMV disease incidence (5.0 and $6.0 \%$ ) at vegetative stage. At reproductive stage, MYMV disease incidence varied significantly among the different genotypes. The lowest disease incidence $(2.0 \%)$ was recorded with genotype SMP17-18 which was statistically at par with SMP17-25 (3.1\%), SMP17-17 (3.2\%), and SMP17-24 (3.6\%). Among the different genotypes, SMP17-28 recorded maximum disease incidence $(23.1 \%)$ which was at par with the genotypes SMP17-31 (22.1\%), SMP17-22 (22.2\%) and SMP17-23 (21.2\%) as against 20 per cent in check i.e. LGG-450.

It is obvious from the results that vegetative stage of the crop is more vulnerable than the reproductive stage which might be due to the presence of high whitefly population appeared on early stage of the crop as compared to reproductive stage. More or less similar results were obtained by Shakoor et al., (1977).

\section{Categorization of mung bean genotypes on the basis of MYMV disease incidence}

Mung bean genotypes under test were further grouped into different categories based on 0 to 9 scale Table 4 by adopting the procedure given by Mayee and Datur (1986). The results revealed that there was great variation among 
genotypes. Out of 16 genotypes under test, none of the genotype was found to be free and highly resistance against MYMV. Four genotypes viz., SMP17-17, SMP17-18, SMP17-24, and SMP17-25 recorded mottling of leaves in 1 to $10 \%$ plants and were found to be resistant $(\mathrm{R})$ at disease rating 3 . Four genotypes i.e. SMP17-19, SMP17-20, SMP17-21 and SMP17-29 exhibited 11 to 20 $\%$ MYMV disease symptoms having rating scale 5 and categorized as moderately resistant (MR)

\section{References}

Anonymous (2016). All India Coordinated Research Project on MULLaRP, ICAR. Project Coordinators Report (Mung bean and Urdbean). IIPR, Kanpur. p. 31.

Chenulu, V.V., Venkateswarlu, V. and Rangaraju, R. (1979). Studies on yellow mosaic disease of mung bean. Indian Phytopathology, 32: 230-235.

Chhabra, K.S. and Kooner, B.S. (1993a). Response of some promising mung bean genotypes towards whitefly, jassids and mung bean yellow mosaic virus. Journal of Insect Science,6(2): 215-218.

Chhabra, K.S. and Kooner, B.S. (1993b). Screening of mung bean germplasm against insect pests and yellow mosaic virus. Indian Journal of Pulses Research, 6(1): 69-75.

Dhingra, K.L. And Chenulu, V.V. (1985). Effect of yellow mosaic on yield and nodulation of soybean. Indian Phytopathology, 38: 248-251.

Iqbal, U., Iqbal, S.M., Afzal, R., Jamal, A., Farooq, M.A. and Zahid, A. (2011). Screening of mung bean germplasm against mung bean yellow mosaic virus (MYMV) under field conditions. Pakistan Journal of Phytopathology, 23(1): 48-51.
Lal, S.S. (1985). A review of insect pests of mung bean and their control in India. Tropical Pest Management, 31: 105114.

Marimuthu, Subramanian, C.L. and Mohan, R. (1981). Assessment of yield loss due to yellow mosaic infection in mung bean. Pulse Crops News, 1: 104.

Mayee, C.D. and Datar, V.V. (1986). Phytopathometry Tech bull.-1, Marathawara Agril. University, Parabhani. Pp. 75-76.

Nair, R.M., Schafleitner, R., Kenyon, L., Srinivasan, R., Ebetand, A.W. and Hanson, P. (2013). Genetic improvement of mung bean, Sambro. Journal of Plant Breeding and Genetics, 44(2): 177-190.

Naqvi, S.H., Talpur, M.A., Rustamani, M.A., Khan, M.M., Hussain, T., Ahmad, M. and Shakoori, A.R. (1995). Relative resistance of mung bean, Vigna radiata (L.) Wilczek, varieties to whitefly and yellow mosaic virus. Fifteenth Pakistan Congress of Zoology held in Islamabad, Pakistan, 1995. Proceedings of Pakistan Congress of Zoology, 15: 247- 251.

Nene, Y.L. (1973). A study of viral disease of pulse crop in Utter Pradesh. Research Bulletin No4, G. B. Pant Univ, Agric. And Tech, Panthnagar, U.P., p-144.

Patel, M.B. and Srivastava, K.P. (1990a). Field screening of some high yielding genotypes of mung bean, Vigna radiata (L.) Wilczek. To whitefly, Bemisia tabaci (Genna.) and yellow mosaic virus (YMV). Indian Journal of Entomology, 52(4): 547-551.

Shakoor, A., Haq, M.A. Sadiq, M.S. and Sarwar, M. (1977). Induction of resistance to yellow mosaic virus in mung bean through induced mutation. Plant diseases, 214: 293-302.

Siddiqui, K.H., Trimohan., Rana, V.K.S. and Lal, S.K. (1999). Location of sources 
of resistance amongst soybean genotypes to yellow mosaic virus disease due to whitefly (Bemisia tabaci Genna). Under natural conditions. Shashpa, 6(1): 37-40.

Singh, G., Singh, K., Gill, A.S. and Chhabra, K.S. (1980). National seminar on disease resistance in crop plants. Tamil Nadu Agricultural University, Coimbatore, 22 and 23 December, 1980.

Suman, S., Sharma, V.K. and Kumar, H. (2015). Screening of mung bean (Vigna radiata (L.) Wilczek) genotypes for resistance to mung bean yellow mosaic virus (MYMV). Environment and Ecology, 33(2A): 855-859.

Taggar, G.K., Gill, R.S. and Sandhu, J.S. (2013). Evaluation of black gram (Vigna mungo (L.) Happer) genotypes to the attack of whitefly, Bemisia tabaci under green-house conditions. Acta Phytopathologica et Entomologica Hungarica. 48(1): 5362.

Yadav, G.S. and Dahiya, B. (2014). Performance of mung bean genotypes against whitefly and yellow mosaic. Annals of Biology, 20(1): 57- 59.

\section{How to cite this article:}

Vinodakumargoud Patil, P.P. Singh, K. Akshay Kumar and Nityashri. 2018. Screening of Mung Bean Genotypes against Whitefly and Yellow Mosaic Viral Disease under Field Condition in Bihar (India). Int.J.Curr.Microbiol.App.Sci. 7(12): 3032-3040.

doi: https://doi.org/10.20546/ijcmas.2018.712.348 